\title{
PENGEMBANGAN E-MODUL BERORIENTASI PEMECAHAN MASALAH UNTUK MENINGKATKAN KETERAMPILAN BERPIKIR KRITIS MAHASISWA
}

\author{
I M. Suarsana \\ Jurusan Pend. Matematika, FMIPA - \\ UNDIKSHA \\ Singaraja, Indonesia \\ email: suarsana1983@gmail.com
}

\author{
G.A. Mahayukti \\ Jurusan Pend. Matematika, FMIPA - \\ UNDIKSHA \\ Singaraja, Indonesia \\ email: gustiayumahayukti@gmail.com
}

\begin{abstract}
The aim of this research was to develop a problem solving oriented e-module of algebra, to analiyze effectiveness of the use of emodule in improving critical thinking skill, and to describe response of students to the e-module. This research was conducted using the design of research and development by adopting a Plomp model as follows: a) preliminary investigation phase, b) design phase, c) realization/construction phase, d) test, evaluation, and revision phase and, e) implementation phase. The result shows that: 1) emodule has been prepared good quality, but still need to be refined again, 2) critical thinking skill of students can be enhanced to good level, 3) the response of students to the lectures which implemented using the e-module is very positive
\end{abstract}

Keywords-e-module; critical thinking skill; problem solving

\section{PENDAHULUAN}

Salah satu tantangan pendidikan dewasa ini adalah membangun keterampilan abad 21, diantaranya adalah keterampilan melek teknologi informasi dan komunikasi (information \& communication technology literacy skill), keterampilan berpikir kritis (critical thinking skill), keterampilan memecahkan masalah (problem solving skill), keterampilan berkomunikasi efektif (effective communication skill) dan keterampilan berkolaborasi (collaborate skill). Keterampilan tersebut itulah yang menurut Perserikatan Bangsa Bangsa (PBB) merupakan ciri dari masyarakat era global saat ini, yaitu masyarakat berpengetahuan (knowledge-based scoeity) (Chaeruman, 2010).

Teknologi informasi dan komunikasi (TIK), memiliki potensi yang sangat besar sebagai sarana atau alat untuk mengembangkan keterampilan tersebut dalam proses pembelajaran. Mac Kinnon (dalam Muderawan, 2011) menyatakan bahwa teknologi akan membantu mengembangkan semua jenis keterampilan berpikir mulai dari tingkat yang paling mendasar hingga tingkat keterampilan berpikir kritis. Oleh karena itu, dalam pendidikan modern, dosen dituntut untuk mampu mengintegrasikan TIK dalam proses pembelajaran. TIK seharusnya tidak hanya dijadikan objek yang harus dipelajari atau memposisikan mahasiswa sebagai orang yang belajar TIK namun apa yang seharusnya terjadi adalah dalam proses pembelajaran harus menggunakan TIK sehingga mahasiswa sekaligus belajar TIK di sana (learning with or trhough ICT).

Seiring dengan pesatnya perkembangan TIK terutama internet maka peluang penerapan elearning sangat besar. Purwaningsih \& Pujianto (2009) menyatakan pemanfaatan e-learning di LPTK merupakan hal yang urgen karena dapat menularkan dan melatih para calon pendidik untuk cakap menggunakan teknologi dalam pembelajaran. Nurchali (2010) juga menyatakan bahwa pemanfaatan komputer dalam pembelajaran dapat memberikan pengalaman belajar yang banyak dan variatif, meningkatkan motivasi belajar serta mengembangkan keterampilan TIK (Teknologi Informasi dan Komputer) mahasiswa. Keterampilan TIK yang diperoleh ini tentunya akan sangat bermanfaat ketika mereka bekerja dan dalam kehidupannya nanti. Terkadang untuk menjadi guru yang profesional, kemampuan kognisi saja tidak cukup, penting juga dilengkapi dengan keterampilan-keterampilan tertentu misalnya di bidang TIK. Apalagi saat ini masih sedikit guru yang mampu memanfaatkan komputer dalam pembelajarannya (Sucita, 2010).

Banyak keuntungan yang dapat dipetik melalui penerapan e-learning, dua diantaranya yang utama adalah meningkatkan efektivitas dan fleksibilitas pembelajaran (Surjono, 2009; Praherdhiono, 2011; Gozali \& Billian, 2011; Mertasari, 2011; Santosa, 2011). Melalui elearning pembelajaran dapat dilakukan kapan saja dan dimana saja, tidak terikat ruang dan waktu. Walaupun banyak manfaat yang diperoleh dengan 
menggunakan e-learning namun persentase penggunaannya masih rendah, proses belajar mengajar di perguruan tinggi di Indonesia masih didominasi dengan tatap muka (Gozali \& Billian, 2011).

Bagaimana dengan penggunaan e-learning di Universitas Pendidikan Ganesha (Undiksha)? Saat ini Undiksha telah memiiliki dua portal elearning. Portal pertama dikembangkan sendiri oleh Unit Pusat Komputer Undiksha dan satunya lagi dikembangkan dengan berbasis Moodle. Kedua portal ini telah dikembangkan untuk tife elearning terpadu yaitu memungkinkan dosen untuk mengunggah materi hypermedia dan hiperteks, absensi, evaluasi, forum diskusi dan perpustakaan digital. Dengan telah dimilikinya portal e-learning dan didukung besarnya kapasitas bandwidh internet yang ada yaitu hingga $50 \mathrm{MB}$ maka pengembangan e-learning Undiksha merupakan suatu potensi yang besar. Namun pemanfaatannya belum optimal bahkan dapat dikatakan masih minim (Candiasa, 2009). Lebih lanjut, berdasarkan penelusuran awal pada kedua portal yang ada, dari 478 dosen Undiksha, persentase dosen pengguna elearning aktif yang ada masih kurang dari $10 \%$. Hal ini masih jauh dari harapan mengingat dalam Renstra Undiksha 2010 - 2014 ingin dicapai 90 orang dosen (19\%) aktif menerapkan e-learning dalam perkuliahan.

Selanjutnya, bagaimana dengan perkuliahan aljabar di Jurusan Pendidikan Matematika Undiksha? Berdasarkan pengalaman peneliti sebagai pengampu mata kuliah aljabar tahun akademik 2010/2011 dan 2011/2012, perkuliahan telah menerapkan e-learning dalam tingkat yang paling sederhana yaitu sebagai tempat mengunggah materi dan tugas perkuliahan, bila diibaratkan pemanfaatannya masih layaknya "loker virtual". Dan tentunya dalam hal ini, manfaat elearning belum diperoleh secara optimal padahal fasilitas untuk itu ada. Oleh karenanya, peneliti ingin mengoptimalkan pemanfaatan seluruh tool yang ada di portal e-learning dan mensubtitusi sebagian pembelajaran konvensional (tatap muka) dengan pembelajaran online yang selanjutnya dikenal dengan blended learning atau hybrid learning dengan tujuan sehingga kualitas perkuliahan meningkat.

Menurut Galvin (2011; 261) "Blended learning course is an effective way to teach the skill and promote an evidence-based approach to practice in this area". Hasil penelitian Mangier (2011) merekomendasikan agar pembelajaran mengkolaborasikan antara tatap muka dan online karena sangat cocok dengan kecenderungan budaya belajar di perguruan tinggi. Dalam merancang suatu perkuliahan dengan blended learning ada ungkapan " repot di awal, enak berikutnya", maksud dari ungkapan tersebut adalah yang terpenting dalam penerapan blended learning adalah penyiapan perangkat pembelajaran guna mendukung keberlangsungan dan kelancaran pembelajaran selanjutnya sehingga blended learning dapat meningkatkan kualitas bukan malah lebih rendah kualitasnya dibandingkan perkuliahan tatap muka. Mengingat pada penerapan blended learning menuntut kemandirian mahasiswa dalam belajar, maka pengembangan perangkat pembelajaran yang diprioritaskan adalah e-modul (elektronik-modul).

E-modul merupakan suatu modul berbasis TIK, kelebihannya dibandingkan dengan modul cetak adalah sifatnya yang interaktif memudahkan dalam navigasi, memungkinkan menampilkan/memuat gambar, audio, video dan animasi serta dilengkapi tes/kuis formatif yang memungkinkan umpan balik otomatis dengan segera. Mertasari (2010) menambahkan bahwa penggunaan modul web dan pembelajaran bermedia akan menjamin kontrol mahasiswa, fleksibilitas, bebas konteks dan juga relative bebas konvensi sosial. E-modul yang akan dikembangakan dalam penelitian ini disusun menggunakan software eXe. Sofware ini merupakan freeware yang dapat diunduh pada http://eXelearning.org yang dikembangkan oleh Sandi Britain etc (2004) dan didukung oleh CORE Education. Beberapa keunggulan penggunaaan software ini diantaranya: 1) mudah digunakan, tampilan sangat user friendly dan tanpa membutuhkan penguasaan bahasa pemrograman tertentu dalam penggunaannya, 2) terdapat i-device seperti java applet dan kuis online sehingga memungkinkan memasukkan aplikasi java dan kuis/tes online dengan balikan yang bersifat segera dan 3) adanya mode insert text berbentuk latex sehingga memudahkan dalam pembuatan equation matematika.

E-modul seperti apa yang dikembangkan? Emodul yang dikembangkan berorientasi pemecahan masalah. Hal ini untuk menjawab permasalahan yang peneliti temui selama mengampu perkuliahan dua tahun sebelumnya yaitu rendahnya keterampilan berpikir kritis mahasiswa. Keterampilan berpikir kritis adalah keterampilan mengidentifikasi fakta yang relevan, mengenali keterbatasan, asumsi-asumsi atau kekhususan yang berkaitan dengan prosedur yang digunakan, dan menentukan jawaban yang rasional (Krulick dan Rudnick, 1996). Dari analisis hasil 
ujian tengah semester mahasiswa pada perkuliahan aljabar tahun akademik 2011/2012, sebagian besar mahasiswa gagal dalam menjawab soal-soal yang menuntut keterampilan berpikir kritis. Misalnya ketika diberikan soal berikut.

$$
\begin{aligned}
& \text { Andaikan } a>0, b>0 \text { dan } c<2 \text {. Kondisi yang } \\
& \text { manakah yang tidak digunakan ketika } \\
& \text { menunjukkan bahwa grafik fungsi kuadrat } \\
& f(x)=a x^{2}+b x+c \text { selalu memotong garis } \\
& y=2 \text { ? Mengapa? }
\end{aligned}
$$

Berdasarkan koreksi terhadap jawaban yang diberikan mahasiswa diperoleh sebaran sebagai berikut : ada 20\% mahasiswa mengosongkan lembar jawaban, $40 \%$ memberikan jawab tanpa alasan, 30\% mahasiswa memberikan jawaban tapi alasan masih keliru, dan hanya ada $10 \%$ yang mampu menjawab dengan sempurna. Hal ini mengindikasikan bahwa mahasiswa gagal membedakan antara informasi, alasan, dan tuntutan-tuntutan yang relevan dengan yang tidak relevan dan berarti bahwa keterampilan berpikir kritis mahasiswa masih rendah.

Penggunaan e-modul berorientasi pemecahan masalah akan menuntun mahasiswa untuk mencari pemecahan masalah secara mandiri dan hal ini akan memberikan suatu pengalaman konkret dalam pemecahan masalah sehingga menumbuhkan dan melatih keterampilan berpikir tingkat tinggi termasuk keterampilan berpikir kritis. Hal ini sesuai dengan pendapat Shadiq (2012) menyatakan bahwa salah satu upaya yang dilakukan untuk mengembangkan kemampuan berpikir kritis sebagai tuntutan era global adalah membiasakan peserta didik melakukan pemecahan masalah bukan saja diakhir pembelajaran tetapi di awal pembelajaran dengan menjadikan pemecahan masalah sebagai suatu pendekatan pembelajaran matematika. Pendapat ini diperkuat juga oleh Trianto (2009) yang menyatakan bahwa Pengajaran berdasarkan masalah meupakan pendekatan yang efektif untuk pengajaran proses berpikir tingkat tinggi termasuk didalamnya kemampuan berpikir kritis. Hasil penelitian terdahulu Suarsana \& Parwati (2007) juga menunjukkan bahwa pengembangan modul berorientasi penalaran dan pemecahan masalah berhasil mengembangkan keterampilan berpikir kritis dan kreatif mahasiswa.

Berdasarkan uraian di atas maka tujuan umum dari penelitian ini adalah mengembangkan e-modul aljabar berorientasi pemecahan masalah yang merupakan salah satu konten pendukung dalam pembelajaran online. Secara khusus penelitian ini ditujukan untuk mendeskripsikan kualitas modul yang telah dikembangkan, mengetahui efektifitas e-modul dalam upaya meningkatkan keterampilan berpikir kritis mahasiswa serta mengetahui tanggapan mahasiswa terhadap penggunaan e-modul dalam perkuliahan aljabar.

\section{METODE}

Penelitian ini adalah penelitian pengembangan, karena dalam pelaksanaannya mengembangkan bahan ajar berupa e-modul aljabar berorientasi pemecahan masalah untuk meningkatkan kemampuan berpikir kritis mahasiswa. E-modul dikembangkan dengan menggunakan perangkat lunak eXe dengan merujuk pada model pengembangan Plomp. Menurut Plomp (1997), pelaksanaan pengembangan meliputi beberapa fase seperti: 1) fase investigasi awal; 2) fase design/perancangan; 3) fase realisasi/konstruksi; 4) fase tes, evaluasi dan revisi; dan 5) fase implementasi.

Subjek penelitian ini adalah mahasiswa yang memprogram kuliah aljabar semester ganjil tahun akademik 2012/2013 di kelas A sebanyak 34 orang.

Data yang dikumpulkan dalam penelitian ini meliputi: data kualitas modul, data keterampilan berpikir kritis dan data tanggapan mahasiswa terhadap pelaksanaan perkuliahan menggunakan emodul. Instrumen pengumpul data yang digunakan dalam penelitian ini adalah: draft modul beserta instrumen penilaiannya, tes keterampilan berpikir kritis, angket tanggapan, dan catatan lapangan.

Kualitas modul ditentukan berdasarkan hasil validasi yang dilakukan oleh para pakar. Ada 4 komponen yang divalidasi yaitu dari segi isi, desain pembelajaran, tampilan visual dan pemanfaatan software pendukung. Kualitas modul ditentukan oleh gabungan skor dari keempat komponen tersebut. Total skor maksimum adalah 70. Kualitas modul dinyatakan dengan perolehan nilai yang dihitung dengan rumus berikut.

$$
\text { Nilai }=\frac{\text { skortotalyangdiperoleh }}{70} \times 100
$$


Kriteria nilai diberikan sebagai berikut.

Tabel 1. Kriteria Konversi Nilai Modul

\begin{tabular}{|l|l|}
\hline \multicolumn{1}{|c|}{ Nilai } & \multicolumn{1}{|c|}{$\begin{array}{c}\text { Kategori } \\
\text { Kualitas E- } \\
\text { Modul }\end{array}$} \\
\hline nila $i<50$ & Kurang \\
\hline $50<$ nila $i \leq 70$ & Cukup \\
\hline $70<$ nila $i \leq 90$ & Baik \\
\hline $90<$ nilai $\leq 100$ & Sangat Baik \\
\hline
\end{tabular}

(Kemendiknas, 2010)

Keterampilan berpikir kritis dan tanggapan mahasiswa terhadap pelaksanaan pembelajaran menggunakan e-modul dianalisis menggunakan statistik deskriptif yaitu menggunakan skor ratarata secara klasikal. Adapun skor yang diperoleh dikonversi menggunakan pedoman di bawah ini.

Tabel 2. Kriteria Konversi Skor Keterampilan Berpikir Kritis dan Tanggapan Mahasiswa

\begin{tabular}{|c|c|c|}
\hline \multirow{2}{*}{ Rentangan Skor } & \multicolumn{2}{|c|}{ Kategori } \\
\cline { 2 - 3 } & $\begin{array}{c}\text { Keterampilan } \\
\text { Berpikir } \\
\text { Kritis }\end{array}$ & Tanggapan \\
\hline$X_{D} \geq M I+1,5 S D I$ & $\begin{array}{c}\text { Sangat } \\
\text { Tinggi }\end{array}$ & $\begin{array}{c}\text { Sangat } \\
\text { positif }\end{array}$ \\
\hline$M I+1,5 S D I>X_{D} \geq M I+0,5 S D I$ & Tinggi & Positif \\
\hline$M I+0,5 S D I>X_{D} \geq M I-0,5 S D I$ & Sedang & Sedang \\
\hline$M I-0,5 S D I>X_{D} \geq M I-1,5 S D I$ & Rendah & Negatif \\
\hline$M I-1,5 S D I>X_{D}$ & $\begin{array}{c}\text { Sangat } \\
\text { Rendah }\end{array}$ & $\begin{array}{c}\text { Sangat } \\
\text { negative }\end{array}$ \\
\hline
\end{tabular}

Keterangan :

$X_{P}=$ Skor rata - rata mahasiswa sec ara klasikal

$M I=\frac{1}{2}($ Skor tertinggi ideal + skor terendahideal $)$

$S D I=\frac{1}{6}($ Skor tertinggi ideal + skor terendahideal $)$

(Nurkancana dan Sunartana, 1990)

Tes keterampilan berpikir kritis terdiri dari 5 item dengan skor maksimum masing-masing butir soal adalah 10 dan skor minimumnya 0 . Sedangkan angket menggunakan skala likert dengan banyak item 10 pernyataan. Dengan demikian untuk skor maksimum dan minimum tes dan angket adalah 50 dan 0 sehingga akan diperoleh table konversi sebagai berikut.

Tabel 3. Kriteria Konversi Skor Motivasi Belajar dan Tanggapan Mahasiswa

\begin{tabular}{|l|l|l|}
\hline \multirow{2}{*}{ Rentangan Skor } & \multicolumn{2}{|c|}{ Kategori } \\
\cline { 2 - 3 } & $\begin{array}{c}\text { Keterampilan } \\
\text { Berpikir Kritis }\end{array}$ & Tanggapan \\
\hline $37,45 \leq X_{P}$ & Sangat Tinggi & $\begin{array}{l}\text { Sangat } \\
\text { positif }\end{array}$ \\
\hline
\end{tabular}

\begin{tabular}{|l|l|l|}
\hline $29,15 \leq X_{P}<37,45$ & Tinggi & Positif \\
\hline $20,85 \leq X_{P}<29,15$ & Sedang & Sedang \\
\hline $12,55 \leq X_{P}<20,85$ & Rendah & Negatif \\
\hline$X_{P}<12,55$ & Sangat Rendah & $\begin{array}{l}\text { Sangat } \\
\text { negatif }\end{array}$ \\
\hline
\end{tabular}

Berdasarkan analisis data yang dilakukan, maka ditetapkan 3 indikator keberhasilan dari penelitian ini yaitu sebagai berikut.

i. Kualitas modul minimal berada pada kategori baik.

ii. Keterampilan berpikir kritis mahasiswa minimal berada pada kategori tinggi.

iii. Tanggapan mahasiswa terhadap pelaksanaan perkuliahan minimal berada pada kategori positif.

\section{A. Hasil}

\section{HASIL DAN PEMBAHASAN}

\section{Kualitas E-modul}

Validasi e-modul melibatkan 2 orang ahli yaitu ahli I adalah ahli di bidang matematika dan pembelajaran matematika yang akan menilai komponen isi dan desain pembelajaran dan ahli II adalah ahli di bidang media pembelajaran yang menilai komponen tampilan dan pemanfaatan software pada e-modul.

Adapun hasil penilaian ahli pada masingmasing komponen adalah sebagai berikut.

Tabel 4. Hasil Penilaian E-modul per Komponen

\begin{tabular}{|l|c|c|c|}
\hline $\begin{array}{c}\text { Komponen } \\
\text { Penilaian }\end{array}$ & $\begin{array}{c}\text { Skor } \\
\text { Maksimu } \\
\mathbf{m}\end{array}$ & $\begin{array}{c}\text { Skor } \\
\text { Peroleha } \\
\mathbf{n}\end{array}$ & $\begin{array}{c}\text { Persen } \\
\text {-tase }\end{array}$ \\
\hline Isi & 13 & 11 & $84,6 \%$ \\
\hline $\begin{array}{l}\text { Desain } \\
\text { pembelajaran }\end{array}$ & 26 & 21 & $80,8 \%$ \\
\hline $\begin{array}{l}\text { Tampilan } \\
\text { visual }\end{array}$ & 19 & 13 & $68,4 \%$ \\
\hline $\begin{array}{l}\text { Pemanfaatan } \\
\text { software }\end{array}$ & 11 & 8 & $72,7 \%$ \\
\hline Total & 70 & 53 & $75,5 \%$ \\
\hline
\end{tabular}

Total skor yang diperoleh adalah 53 dengan skor maksimum adalah 70. Bila skor ini dikonversi ke skala 100 diperoleh nilai e-modul adalah 75,5. Berdasarkan kriteria yang ditetapkan maka dapat disimpulkan e-modul berada pada kategori baik.

Ada beberapa kelebihan dan kelemahan yang ditemukan pada prototype ini yaitu sebagai berikut. 
Kelebihan:

- Cakupan materi yang eksploratif yaitu mendorong mahasiswa untuk mencari informasi sebanyak-banyaknya dari berbagai sumber.

- Inovatif yaitu memunculkan hal-hal baru dalam pendekatan penyajian suatu konsep. modul dengan latihan/tes/simulasi yang bersifat interaktif dan dapat memberikan umpan balik dengan segera

- Dilengkapinya modul dengan navigasi yang memudahkan pembaca menelusuri isi modul dengan cepat.

- Telah ada interaktivitas walaupun hanya pada butir soal.

- Telah menggunakan beberapa software pendukung.

Kelemahan:

- Kurang lengkapnya cakupan materi sehingga emodul ini tidak tepat dijadikan bahan ajar utama tetapi lebih tepat sebagai suplemen materi.

- Materi tidak lengkap, belum ada apersepsi dan pengayaan

- Tidak dilengkapinya e-modul dengan contohcontoh soal

- Baru menggunakan media gambar saja belum dilengkapi animasi.

- Interaktivitas yang dilakukan mahasiswa belum disimpan dalam database

Pada bagian akhir dari instrumen evaluasi, kedua ahli diminta untuk memberikan rekomendasi akhir dari media yang dinilai. Kedua ahli menyatakan bahwa e-modul ini masih perlu diperbaiki lagi dan agar media ini layak sebagai bahan ajar utama maka harus dilakukan perbaikanperbaikan terutama melengkapi uraian materi dan menambahkan beberapa contoh-contoh soal.

\section{Keterampilan Berpikir Kritis dan Tanggapan Mahasiswa}

Ujicoba dilakukan untuk Bab 1 Persamaan dan Fungsi Kuadrat. Perkuliahan dilakukan selama 3 kali tatap muka dengan suplemen pembelajaran online. Setelah pembahasan Bab 1 selesai, diadakan tes untuk mengukur keterampilan berpikir kritis mahasiswa. Tes terdiri dari 5 butir soal yang disusun mengacu pada 5 indikator keterampilan berpikir kritis yang telah ditetapkan sebelumnya. Adapun perolehan skor mahasiswa adalah sebagai berikut.
Tabel 5. Ukuran Data Skor Tes Keterampilan Berpikir Kritis Persamaan dan fungsi Kuadrat

\begin{tabular}{|l|l|}
\hline Ukuran Data & Nilai \\
\hline Rata-rata & 27,6 \\
\hline Standar Deviasi & 11,3 \\
\hline Skor Maksimum & 40 \\
\hline Skor Minimum & 15 \\
\hline Skor Maksimum Ideal & 50 \\
\hline
\end{tabular}

Berdasarkan kriteria yang ditetapkan maka rata-rata keterampilan berpikir kritis mahasiswa berada pada kategori sedang.

Ada beberapa temuan penting terkait uji coba e-modul dalam perkuliahan aljabar yaitu di antaranya sebagai berikut.

1. Awalnya mahasiswa menghadapi kendala teknis dalam pembelajaran online misalnya lupa user dan password pada saat mendaftar di awal, belum mengenal dengan baik fiturfitur yang disediakan, dan tidak bisa berpartisipasi dalam forum dan tes formatif online.

2. Partisipasi mahasiswa dalam forum diskusi online masih rendah.

Beberapa perbaikan dilakukan untuk lebih mengoptimalkan penggunaan e-modul dalam pembelajaran aljabar yaitu sebagai berikut.

1. Mengintegrasikan permasalahan yang diberikan pada modul menjadi bahan diskusi pada forum.

2. Mengasumsikan mahasiswa dianggap hadir dalam kelas online jika telah mendownload materi, berpartisipasi di forum diskusi dan mengerjakan kuis online.

3. Memberikan skor pada mahasiswa bukan hanya pada yang ikut kuis tetapi juga bagi yang berpartisipasi dalam kegiatan forum diskusi yang disediakan.

Berdasarkan perbaikan tersebut selanjutnya perkuliahan aljabar untuk Bab 2 Suku Banyak kembali menggunakan e-modul berorientasi pemecahan masalah. Pertemuan tatap muka dilakukan sebanyak 3 kali dengan suplemen pembelajaran online. Setelah pembahasan Bab 2 rampung, kembali diadakan tes keterampilan berpikir kritis yang terdiri dari 5 item soal.

Adapun perolehan skor mahasiswa adalah sebagai berikut. 
Tabel 6. Ukuran Data Skor Tes Keterampilan Berpikir Kritis Suku Banyak

\begin{tabular}{|l|c|}
\hline \multicolumn{1}{|c|}{ Ukuran Data } & Nilai \\
\hline Rata-rata & 31,4 \\
\hline Standar Deviasi & 10,6 \\
\hline Skor Maksimum & 44 \\
\hline Skor Minimum & 20 \\
\hline Skor Maksimum Ideal & 50 \\
\hline
\end{tabular}

Berdasarkan kriteria yang ditetapkan maka rata-rata keterampilan berpikir kritis mahasiswa berada pada kategori tinggi.

Selanjutnya tanggapan mahasiswa terhadap penggunaan e-modul dalam perkuliahan aljabar diukur dengan menggunakan angket dan diperoleh hasil sebagai berikut.

Tabel 7. Ukuran Data Tanggapan Mahasiswa

\begin{tabular}{|l|c|}
\hline \multicolumn{1}{|c|}{ Ukuran Data } & Nilai \\
\hline Rata-rata & 36 \\
\hline Standar Deviasi & 8,4 \\
\hline Skor Maksimum & 46 \\
\hline Skor Minimum & 34 \\
\hline Skor Maksimum Ideal & 50 \\
\hline
\end{tabular}

Berdasarkan kriteria yang ditetapkan maka rata-rata tanggapan mahasiswa terhadap penggunaan e-modul berada pada kategori sangat positif.

\section{B. Pembahasan}

Pengembangan e-modul berorientasi pemecahan masalah membutuhkan berbagai tahapan mulai dari fase investigasi awal, fase perancangan, fase realisasi/konstruksi, fase tes/evaluasi dan revisi serta fase implementasi.

Pada investigasi awal, teridentifikasi dua permasalahan utama yang perlu diperhatikan dan mendapat penanganan dalam pembelajaran antara lain: pemanfaatan e-learning yang belum optimal dan rendahnya keterampilan berpikir kritis mahasiswa. Berdasarkan kajian dilakukan dirancanglah langkah pemecahan berupa pengembangan e-modul berorientasi pemecahan masalah. Selanjutnya pada tahap design/perancangan model dilakukan desain emodul dan juga instrument penelitian pendukungnya seperti lembar penilaian modul, tes keterampilan berpikir kritis dan angket tanggapan mahasiswa. Pada tahap realisasi, modul dan instrument penelitian disusun berdasarkan desain yang telah dibuat sehingga dihasilkan prototype produk.

Setelah prototype e-modul dihasilkan, dilakukan penilaian oleh ahli di bidangnya. Dari hasil penilaian terungkap beberapa kelebihan dan kelemahan yang ada pada e-modul yang dikembangkan ini. Secara keseluruhan e-modul yang dihasilkan telah berkualitas baik. Hal ini berarti e-modul yang dihasilkan telah memenuhi aspek kelayakan baik dari segi isi, desain pembelajaran, tampilan visual dan pemanfaatan software pendukung. Keempat komponen tersebut merupakan komponen utama yang mesti diperhatikan dalam pengembangan bahan ajar berbasis TIK (Kemendiknas, 2010).

Menindaklanjuti hasil validasi dari masingmasing ahli selanjutnya diadakan perbaikan di antaranya sebagai berikut.

1) Uraian materi dibuat lebih lengkap dan detail dengan melengkapinya dengan apersepsi, contoh soal dan pengayaan.

2) Perbanyak jumlah dan variasi penggunaan media seperti gambar, animasi atau video.

Agar e-modul yang dihasilkan bisa berkualitas dan cukup valid digunakan maka memerlukan beberapa kali uji coba. Dalam penelitian ini, hal ini belum bisa dilakukan sepenuhnya karena waktu yang tidak memungkinkan. Ujicoba yang dilakukan adalah uji coba secara terpakai pada perkuliahan Aljabar di kelas A pada semester ganjil tahun akademik 2012/2013 yaitu dengan jumlah mahasiswa 34 orang.

Dilihat dari keterampilan berpikir kritis mahasiswa pada uji coba siklus 1, tergolong sedang, berarti belum sesuai dengan harapan. Berdasarkan hasil pengamatan, hal ini terjadi karena dalam mengikuti perkuliahan, utamanya perkuliahan online banyak mahasiswa mengalami kendala teknis dan belum tahu fitur-fitur yang tersedia dalam portal elearning yang dalam hal ini digunakan learning management system (LMS) moodle. Banyak mahasiswa belum berpartisipasi dalam forum diskusi online yang disediakan. Mereka mendownload e-modul yang diberikan tanpa berbagi tanggapan terhadap isi dari e-modul. Dalam konteks ini, e-modul belum dimanfaatkan atau diekplorasi secara optimal oleh mahasiswa.

Upaya pemecahan yang ditempuh terkait dengan masalah ini adalah mensosialisasikan fiturfitur moodle yang bisa dikelola mahasiswa, mengintegrasikan permasalahan yang diberikan pada modul menjadi bahan diskusi pada forum, menetapkan bahwa mahasiswa dianggap hadir di kelas online jika telah mendownload materi, 
berpartisipasi di forum diskusi dan mengerjakan kuis online, serta memberikan skor pada mahasiswa bukan hanya pada yang ikut kuis tetapi juga bagi yang berpartisipasi dalam kegiatan forum diskusi yang disediakan.

Dengan perbaikan tersebut kembali diadakan uji coba siklus 2 untuk topik Suku Banyak. Hasil tes keterampilan berpikir kritis menunjukkan terjadi peningkatan baik secara kuantitas maupun kualitas yaitu dari rata-rata 27,6 (sedang) menjadi 31,4 (tinggi). Hasil ini telah memenuhi indikator keberhasilan yang ditetapkan. Beberapa hal yang diyakini berperan besar dalam pencapaian peningkatan ini adalah hal-hal berikut.

Pertama, e-modul disusun menggunakan pendekatan pemecahan masalah yang mengarahkan mahasiswa untuk melakukan pemecahan masalah. Hal ini secara langsung akan melatih mahasiswa berpikir kritis. Hasil ini menegaskan kembali apa yang telah diperleh pada penelitian sebelumnya yang menunjukkan bahwa penggunaan modul berorientasi penalaran dan pemecahan masalah berhasil mengembangkan keterampilan berpikir kritis dan kreatif mahasiswa. Hal senada diungkapkan oleh Trianto (2009) yang menyatakan bahwa Pengajaran berdasarkan masalah meupakan pendekatan yang efektif untuk pengajaran proses berpikir tingkat tinggi termasuk didalamnya kemampuan berpikir kritis.

Kedua, lingkungan belajar online yang memungkinkan mahasiswa mengekplorasi informasi dari berbagai sumber dengan cepat dan mudah. Hal ini akan mendorong mahasiswa belajar untuk kritis dan selektif dalam memilih informasi yang ada sesuai permasalahan yang diberikan. Mahasiswa dapat mengontrol pembelajarannya sendiri, mereka bebas menentukan cara belajarnya sendiri. Mertasari (2010) menambahkan bahwa penggunaan modul web dan pembelajaran bermedia akan menjamin kontrol mahasiswa, fleksibilitas, bebas konteks dan juga relative bebas konvensi sosial. Hasil ini menegaskan apa yang diungkapkan Mac Kinnon (dalam Muderawan, 2011) yang menyatakan bahwa teknologi akan membantu mengembangkan semua jenis keterampilan berpikir mulai dari tingkat yang paling mendasar hingga tingkat keterampilan berpikir kritis.

Ketiga, adanya forum diskusi online yang mendorong semua mahasiswa berpendapat sehingga mereka terlatih untuk menanggapi atau mengkritisi pendapat teman mereka yang kurang sesuai dengan pemahaman mereka. Kesempatan bertanya dan menanggapi di forum diskusi online sangat terbuka lebar dan luas sehingga mendorong terbentuknya komunitas belajar. Sunarto (2011) menyatakan bahwa keberadaan komunitas belajar akan membawa dampak pada peningkatan kualitas dan kedalaman berpikir serta mendorong proses inkuiri. Keduanya akan berdampak langsung pada peningkatan keterampilan berpikir kritis.

Tanggapan mahasiswa terhadap perkuliahan menggunakan e-modul yang dikembangkan adalah sangat positif. Hal ini menandakan mereka sudah dapat menikmati cara belajar yang diterapkan dengan tidak merasakan sebagai suatu beban. Di awal memang meraka merasa agak kesulitan mengikuti perkuliahan sebab sebagian dari mereka belum pernah belajar dalam lingkungan online, tetapi setelah berjalan beberapa pertemuan mereka mulai menyenanginya dan telah tumbuh kemandirian dalam belajar.

\section{SIMPULAN DAN SARAN}

Berdasarkan hasil penelitian dan pembahasan dapat disimpulkan beberapa hal sebagai berikut: (1) Modul yang disusun telah berkualitas baik dan masih perlu disempurnakan lagi. (2) Melalui penggunaan e-modul berorientasi pemecahan masalah, keterampilan berpikir kritis mahasiswa mengalami peningkatan dari rata-rata 27,6 (sedang) pada siklus I menjadi 31,4 (tinggi) pada siklus II. (3) Tanggapan mahasiswa terhadap pelaksanaan perkuliahan menggunakan e-modul berorientasi pemecahan masalah adalah sangat positif.

Beberapa saran yang dapat disampaikan dalam hal ini adalah sebagai berikut. (1) Penggunaan e-modul dalam pembelajaran memerlukan persiapan yang matang terutama dalam penyiapan lingkungan belajar online dan pengelolaan interaksi dengan mahasiswa sehingga keberadaannya dapat meningkatkan kualitas perkuliahan dan bukan sebaliknya. (2) Perlu penelitian lebih lanjut terutama untuk melihat dampak penerapan pembelajaran berbantuan emodul berorientasi pemecahan masalah terhadap berbagai komponen kualitas pembelajaran.

\section{REFERENSI}

[1] Candiasa. I.M. 2009. Optimalisasi Portal E-learning Undiksha sebagai Komplemen Perkuliahan Konvensional. Makalah disajikan pada workshop yang diselenggarakan oleh LP3 Undiksha tanggal 5 Desember 2009

[2] Chaeruman, Uwes. 2010. E-Learning dalam Pendidikan Jarak Jauh. Jakarta : Kemendiknas

[3] Galvin, B. 2011. "A Blended Learning Course Teaching Information Literacy For Substance Use Prevention Work" Journal of information Literacy. Volume 5 issue 1. Hal $65-88$ 
ISSN 2089-8673

Jurnal Nasional Pendidikan Teknik Informatika (JANAPATI)

Volume 2, Nomor 3, Desemer 2013

[4] Gozali, F. dan Billion Lo. 2011. "Pemanfaatan Teknologi Open Source dalam Pengembangan Proses Belajar Jarak Jauh di Perguruan Tinggi ". Makalah disajikan dalam Seminar Nasional Optimalisasi Pemanfaatan Aplikasi TIdalam Dunia Pendidikan. Jurusan Pendidikan Teknik Informasika. Singaraja. 20 September 2011

[5] Kemendiknas. 2010. Panduan Pengembangan Bahan Ajar Berbasis TIK. Jakarta : Dirjen Manajemen Pendidikan dasar dan Menengah

[6] Muderawan, I.W. 2011. "Perkembangan Teknologi Informasi dan Komunikasidan Aplikasinya dalam Pembelajaran". Makalah disajikan dalam Seminar Nasional Optimalisasi Pemanfaatan Aplikasi TIdalam Dunia Pendidikan. Jurusan Pendidikan Teknik Informasika. Singaraja. 20 September 2011

[7] http:// eXelearning.org

[8] Nurchali.2010. Pengaruh Media Pembelajaran Berbasis Teknologi Informasi dalam Pembelajaran Kimia Terhadap Peningkatan Hasil Belajar Mahasiswa. Jurnal Pendidikan dan Kebudayaan. Volume 16. Halaman 648 658.

[9] Plomp, T. 1997. Educational and Training Sistem Design. Enschede: University of Twente

[10] Purwaningsih, D dan Pujianto. 2009. "Blended Cooperative E-learning sebagai sarana Pendidikan Penunjang Learning Community" makalah disampaikan dalam seminar nasional UNY dengan tema Peranan ICT dalam Pembelajaran. Yogyakarta, 25 Juli 2009.

11] Santosa, P.I. 2011. "Model Konseptual Pemanfaatan teori Flow dalam E-learning". Makalah disajikan dalam Seminar Nasional Optimalisasi Pemanfaatan Aplikasi TIdalam Dunia Pendidikan. Jurusan Pendidikan Teknik Informasika. Singaraja. 20 September 2011

[12] Shadiq, F. 2012. Pentingnya pemecahan Masalah. Tersedia pada http://p4tkmatematika.org/file/problemsolving/Pemecaha n Masalah SMP.pdf (diakses tanggal 10 Januari 2012)

[13] Suarsana, I. M. dan Ni Nyoman Parwati. 2007. Pengembangan Modul Teori Bilangan Berorientasi Penalaran Dan Pemecahan Masalah untuk Mengembangkan Kompetensi Berpikir Tingkat Tinggi Mahasiswa. Laporan Penelitian (tidak diterbitkan). Jurusan Pendidikan Matematika, Undiksha

[14] Sucita, I N. 2010. Pemetaan Kompetensi Guru Matematika. Majalah Saraswati. Edisi II.

[15] Halaman 15-17

[16] Sunarto. 2011. Komunitas Pembelajaran. Tersedia di http://sunartombs.wordpress.com/2011/08/12/komunitaspembelajaran-learning-community/(diakses 8 Nopember 2012).

[17] Surjono, H.D., 2009. Pengantar E-learning dan Penyiapan Materi Pembelajaran. Puskom UNY

[18] Trianto. 2009. Mendesain Model Pembelajaran InovatifProgresif. Jakarta : Kencana Prenada Media Group 